\title{
Relaţia mutuală dintre dinamica synaxei euharistice şi mobilitatea pastoral-misionară a parohiei în gândirea Părintelui Ion Bria
}

\section{Răzvan Emanuel FIBIŞAN}

\begin{abstract}
Undoubtedly, there is an organic link between the Eucharist and the parish. Father Professor Ion Bria is one of Romanian theologians who greatly emphasized this interrelation, saying that missionary mobility of the parish hold, rather, dynamic Eucharistic assembly. From communion with the Body and Blood of Jesus Christ starts the entire activity of the parish.
\end{abstract}

Keywords: basic community, the dynamic of the liturgy, parish community, witness

Părintele profesor Ion Bria este unul dintre teologii români care, într-o lume a separatismului, a indolenţei şi a amalgamului, a reafirmat sensul biblic, autentic al ,,parohiei”, evidenţiind totodată că aceasta înseamnă ,a conlocui” sau, cu alte cuvinte, loc de adunare şi de refugiu pentru pelerini. De asemenea, părintele a reliefat faptul că „parohia” este atât punctul de plecare şi de sosire al vieţii creştine, 
cât şi comunitatea de bază a Bisericii locale'. Preocupat fiind de reorganizarea vieţii parohiale, părintele Bria ţine neapărat să precizeze că viaţa autentică a unei comunităţi parohiale trebuie să se facă în perspectiva unei învăţături clare despre Biserică, pentru că acolo unde teologia şi practica pastorală sunt exercitate fără o referinţă la doctrina ecleziologică şi la spiritualitatea liturgică, comunitatea parohială riscă să fie deformată. De aceea, în gândirea sa, există o analogie între parohie şi Biserică. Parohia, pe lângă faptul că trebuie să se orienteze după Biserică, în sensul că iconomia parohiei trebuie să coincidă cu iconomia Bisericii, ea este chiar un proiect mic în interiorul proiectului mare. Chiar dacă participarea credincioşilor la viaţa parohială depinde, într-o oarecare măsură, de integrarea lor în colectivitatea socială, părintele Bria subliniază că o comunitate parohială nu trebuie asociată cu un anumit cadru sociologic, cultural tradiţional, ci acea comunitate eclezială, prin motivarea ei liturgică şi euharistică, tinde sau trebuie să tindă la ceea ce este Biserica prin însăşi natura ei: ,comunitatea celor care, în prezenţa şi cu puterea Duhului Sfânt, sunt în unitatea trupească şi sufletească a lui Dumnezeu". Din gândirea părintelui reiese apriat faptul că parohia nu este o simplă unitate administrativă bisericească, ci este parte organică dintr-un corp bisericesc unitar, putând influenţa viaţa întregului ansamblu eclezial. În altă ordine de idei, comunitatea parohială nu este o simplă asociaţie voluntară sau o fraternitate oarecare, bazată pe anumite impulsuri comunitare, ci este, mai degrabă, un act de credinţă. Ea nu este „o cooperativă de prestaţii de servicii şi de intervenţii religioase, ci o comunitate a sfinţilor, în unitate de credinţă, de etică şi de slujire. Ea este o instituţie care realizează în timp şi spaţiu Trupul lui Hristos, poporul lui Dumnezeu (I Petru 2, 9-10)”2.

\footnotetext{
${ }^{1}$ Pr. Prof. Dr. Ion Bria, Curs de formare misionară şi ecumenică, Geneva, 1984, p. 20.

${ }^{2}$ Pr. Prof. Dr. Ion Bria, Curs de teologie şi practică misionară ortodoxă, Genève, 1982, pp. 45-46, 78-79.
} 
O problemă imparabilă dezbătută de părintele Bria, mai ales în contextul actual, când comunitatea parohială este dispersată geografic şi complexă din punct de vedere demografic şi cultural, este aceea a întăririi conştiinţei la un singur trup comun. Este cunoscut faptul că, în Ortodoxie, actul care confirmă apartenența vizibilă la Biserica - Trupul lui Hristos este, fără îndoială, Sfânta Euharistie. Cu alte cuvinte, apartenența vizibilă la Biserica istorică este confirmată în şi prin Euharistie. De fapt, părintele Ion Bria acest lucru scoate în relief şi anume: că parohia nu poate exista fără comuniunea euharistică. Ideea părintelui, conform căreia nu poate exista trupul lui Hristos (Biserica) fără Trupul şi Sângele lui Hristos (Sfânta Euharistie), vine şi din faptul că atât comunitatea eclezială, cât şi Euharistia au aceeaşi denumire, de „Trupul lui Hristos”.

Întrucât împărtăşirea cu Sfintele Taine constituie cea mai autentică manifestare a apartenenţei la trupul Bisericii, parohia este văzută de părintele Bria ca fiind ,manifestarea văzută a vieţii în Hristos"4. De aceea, preacucernicia sa consideră că dezintegrarea sau deteriorarea vieţii parohiale îşi are cauza în deprecierea momentului împărtăşirii credincioşilor. El subliniază că, indiferent de vârstă şi preocupări, creştinii nu trebuie ţinuţi în colţul bisericii ca nişte spectatori străini, ci ei trebuie invitaţi să formeze un cerc în jurul potirului, pentru că, de integritatea liturgică a credincioşilor depinde integritatea parohiei. De multe ori subliniază că integritatea

\footnotetext{
${ }^{3}$ Pr. Prof. Univ. Dr. Ion Bria, Spre plinirea Evangheliei. Dincolo de apărarea Ortodoxiei: exegeza şi transmiterea Tradiţiei, Alba-Iulia, Editura Reîntregirea, 2002, pp. 105-106.

${ }^{4}$ Pr. Prof. Dr. Ion Bria, Destinul Ortodoxiei, Bucureşti, Editura Institutului Biblic şi de Misiune al Bisericii Ortodoxe Române, 1989, p. 308. Părintele Bria consideră că o parohie care cunoaşte catehismul pe de rost, dar nu practică împărtăşirea credincioşilor cu Sfintele Taine, este o pseudo-parohie, pentru că a deviat de la înţelegerea raportului dintre Euharistie şi Biserică - Pr. Prof. Dr. Ion Bria, Liturghia după Liturghie. Misiunea apostolică şi mărturie creştină azi, Editura Athena, 1996, pp. 164-165.
} 
vieţii parohiale şi mobilitatea misionară a comunităţii creştine ţin, mai degrabă, de dinamica synaxei euharistices. Reiese de aici că entuziasmul euharistic constituie, în concepţia sa, izvorul nu doar al spiritului de comuniune şi de solidaritate parohială, ci şi al motivării şi al determinării misionare a credincioşilor. De aceea, el pune accent pe restabilirea caracterului public, euharistic şi instructiv al cultului, întrucât această restabilire este o precondiţie a parohiei. Este foarte important ca toţi creştinii să conştientizeze calitatea lor de a fi membri vii ai trupului lui Hristos ce se zideşte cu fiecare dintre ei, prin dialog, cântare şi slujire comună şi, mai ales, prin împărtăşirea cu Trupul şi Sângele lui Hristos ${ }^{6}$. În altă ordine de idei, pentru părintele Bria, împărtăşirea cu Trupul şi Sângele Mântuitorului constituie baza comunităţii creştine, forţa unităţii şi solidarităţii ei şi, mai ales, ancorarea credinciosului în comunitatea - trup hristic: „Iar pe noi pe toţi, care ne împărtăşim dintr-o pâine şi dintr-un potir, să ne uneşti unul cu altul prin împărtăşirea Aceluiaşi Sfânt Duh" faptului că Euharistia actualizează pe Hristos cel înviat, împărtăşirea cu Sfintele Taine constituie, pentru teologul român, rezerva principală a Bisericii/comunităţii parohiale, mai exact, atât forţa ei de coeziune

\footnotetext{
${ }^{5}$ Pr. Prof. Dr. Ion Bria, Curs de teologie şi practică misionară ortodoxă ..., pp. $44,58,84$.

${ }^{6}$ Gheorghe Petraru, Pr. Prof. Dr. Ion Bria - universalizarea şi dinamizarea etosului misionar ortodox, în Rev. ph. D. Ioan Tulcan şi ph. D. Cristinel Ioja (coord.), „Omagiu Părintelui Prof. Dr. Ion Bria (1929-2002): The reception of his theological thinking an its relevance for the overpass of the ecumenical \&missionary deadlock", Arad, Editura Universităţii „Aurel Vlaicu”, 2009, p. 218.

${ }^{7}$ Pr. Prof. Dr. Ion Bria, Curs de teologie şi practică misionară ortodoxăa.., pp. 81, 84; Pr. Prof. Dr. Ion Bria, Ortodoxia în Europa. Locul spiritualităţii române, Iaşi, Editura Mitropoliei Moldovei şi Bucovinei, 1995, p. 225. Teologii ortodocşi afirmă în unanimitate faptul că Biserica a primit în Euharistie atât hrana creşterii în Hristos, cât şi sămânţa înmulţirii ei. Fără îndoială, prin Euharistie, Biserica este o comunitate care „creşte” încontinuu (Cf. Faptelor Apostolilor 2, 41, 47; 5, 14; 6, 7). De asemenea, toţi afirmă că Euharistia nu este numai sămânţa înmulţirii ei, ci şi condiţia existenţei şi unităţii ei.
} 
- adică capacitatea ei de a ţine poporul la un loc şi de a-i da o nouă identitate, care nu este altceva decât rezultatul împăcării cu Dumnezeu şi aproapele -, cât şi sursa ei de misiune, energie şi inspiraţie ${ }^{8} . \mathrm{Cu}$ alte cuvinte, Euharistia este considerată de el ca fïind, ,inima dinamică a comunităţii ecleziale"9. Aceasta înseamnă că, în viziunea sa, ritmul liturgic impune ritmul parohiei. Cele două mari mişcări ale dinamicii Liturghiei - 1. adunarea sau revenirea în sine a comunităţii pentru celebrare şi împărtăşire, care, cu alte cuvinte, înseamnă reconstituirea permanentă a unităţii interioare a poporului lui Dumnezeu; şi 2. trimiterea în afară (Cu pace să ieşim!) sau ieşirea din sine pentru martyria (mărturie), imolare (jertfă) şi slujire, după exemplul lui Hristos care a purtat Crucea ,dincolo” de porţile cetăţii (Evrei 13, 12) - impun parohiei, fără îndoială, un anumit ritm ${ }^{10}$.

${ }^{8}$ Pr. Prof. Dr. Ion Bria, Curs de teologie şi practică misionară ortodoxă..., p. $89,96$.

${ }^{9}$ Ion Bria, Unity and Mission. From the Perspective of the local Church: an Orthodox View, în „The Ecumenical Review”, nr. 3, 1987, p. 267.

${ }^{10}$ În gândirea părintelui Bria, puterea misionară a Liturghiei rezidă în viziunea sa euharistică, care nu este alta decât recapitularea tuturor în Hristos - Ion Bria, Liturgie et mission, în „Dictionnaire oecuménique de missiologie. Cent mots pour la mission", sous la direction de Ion Bria, Philippe Chanson, Jacques Gadille, Marc Spindler, Paris-Geneve-Yaoundé: Edition du Cerf, Labo et Fides, CLE Yaoundé, 2001, p. 190. Trebuie menţionat că, tot din perspectiva celor două mişcări ale dinamicii Liturghiei, părintele profesor creionează şi cele două direcţii ale misiunii Bisericii: 1. misiunea internă (misiunea ad intra), în sensul că Biserica s-a preocupat întotdeauna de cei botezaţi, organizând viaţa internă, liturgică şi socială a comunităţii creştine; şi 2. misiunea externă (misiunea $a d$ extra), în sensul că Biserica a propovăduit Evanghelia mântuirii la toată făptura, indiferent de etnie, limbă şi cultură. Din aceste două perspective, Biserica apare atât ca o comunitate euharistică - poporul lui Dumnezeu răscumpărat care se adună să comemoreze şi să actualizeze iconomia mântuirii -, cât şi ca o comunitate apostolică misionară, care are conştiinţa unei trimiteri speciale la cei din afara Bisericii. Observăm că, la părintele Bria, misiunea se integrează în acţiunea liturgică a Bisericii, care are în centrul ei Taina Euharistiei. Osmoza dintre dimensiunea euharistică şi dimensiunea misionară a Bisericii este evidentă 
În orice caz, împărtăşirea credincioşilor cu Sfintele Taine constituie, pentru părintele profesor, legea de aur a pastoraţiei. Însăşi termenul de „pastoraţie”, spune părintele Bria, (care vine de la pasco, -ere = a hrăni), înseamnă acţiunea de a oferi hrană sau de a întreţine prin mâncare. Prin urmare, pastoraţia în sens religios înseamnă lucrarea de împărtăşire a Sfintelor Taine, care constituie „hrana/merindea" Bisericii ${ }^{11}$. Plecând de aici, părintele exprimă o idee deosebit de importantă. El spune că oferirea Euharistiei, ca hrană şi băutură, pelerinilor şi misionarilor este un act esenţial, pentru că acest act schimbă o comunitate parohială dintr-o adunare liturgică intr-o comunitate mărturisitoare şi evanghelizatoare ${ }^{12}$. De fapt, el subliniază că puterea cea mai mare de evanghelizare o are însăşi comunitatea euharistică sau liturghisitoare, deoarece comuniunea cu Hristos euharistic este cea mai bună cale de comunicare a Evangheliei. El observă că Euharistia face ca cel „,chemat” pentru împărtăşire să devină cel „trimis” pentru propovăduire şi mărturie, având Euharistia drept hrană pentru pelerinaj ${ }^{13}$. Datorită Euharistiei, considerată de

- Pr. Prof. Dr. Ion Bria, Curs de teologie şi practică misionară ortodoxă..., p. $6,45$.

${ }^{11}$ Pr. Prof. Dr. Ion Bria, Curs de teologie şi practică misionară ortodoxă..., pp. 5-6.

${ }^{12}$ Ion Bria, The Liturgy after the Liturgy. Mission and Witness from an Orthodox Perspective, Geneva, WCC Publications, 1996, p. 31; Pr. Prof. Dr. Ion Bria, Liturghia după Liturghie. Misiunea apostolică şi mărturie creştină azi, p. 212. În acest sens, el vorbeşte despre valoarea adunării euharistice nu numai pentru împărtăşirea credincioşilor cu ,„pâinea vieţii”, ci şi despre valoarea adunării euharistice pentru propovăduirea Evangheliei - Ion Bria, „Dynamics of Liturgy in Mission”, în International Review of Mission, LXXXII (1993), nr. 327, p. 317.

${ }^{13}$ În gândirea părintelui Bria, Euharistia ocupă un loc central în mişcarea misionară a Bisericii. Euharistia este văzută drept ,pâinea pelerinilor” sau „hrana cea scumpă pentru misionari” sau ,eveniment misionar” - Ion Bria, The Liturgy after the Liturgy. Mission and Witness from an Orthodox Perspective, $\mathrm{p}$. 28; Ion Bria, Reflection on Mission Theology and Methodology, în „International 
părintele Bria drept „stimulul intern care motivează comunitatea şi pe fiecare persoană spre misiune", comunitatea liturgică (parohia) este o comunitate misionară prin excelenţă sau ,celula misionara” prin excelenţă, deoarece ea (n.r. parohia) este chemată să predice şi să înveţe Evanghelia mântuirii şi să fie martorul lui Hristos în condiţiile specifice orânduite ei de Dumnezeu ${ }^{14}$. Din cele spuse, se observă ceva extraordinar, anume faptul că, în gândirea teologului român, adunarea la cult, celebrarea Euharistiei şi propovăduirea Evangheliei nu sunt puse în concurenţă, ci din contră sunt concomitente şi complementare ${ }^{15}$. De fapt, în concepţia sa, ascultarea şi propovăduirea cuvântului lui Dumnezeu şi împărtăşirea cu Sfintele Taine sunt actele prin care se realizează structura de comuniune a oricărei comunităţi parohiale ${ }^{16}$. Modelul liturgic, pe lângă faptul că nu permite niciun fel de discriminare (pentru că actul liturgic nu ţine cont de particularităţile etnice, culturale, sociale), intenţionează să adâncească comunitatea, să recupereze unitatea ei internă şi să întreţină cooperarea şi activitatea comună ${ }^{17}$. Este evident faptul că, pentru părintele Bria, profilul de ansamblu al parohiei, îndeosebi, expresia ei cultică, euharistică, constituie o sursă de inspiraţie pentru manifestarea interioară şi exterioară a comunităţii, dar şi pentru spiritualitatea şi disciplina credincioşilor. În întreaga sa operă, se poate observa existenţa unui raport între Liturghie şi etică, între

Review of Mission”, nr. 289, 1984, pp. 68-69; Ion Bria, Unity and Mission. From the Perspective of the local Church: an Orthodox View, în „The Ecumenical Review", XXXIX (1987), nr. 3, p. 267; Ion Bria, Liturgie et mission, pp. 191192.

${ }^{14}$ Pr. Prof. Dr. Ion Bria, Liturghia după Liturghie. Misiunea apostolică şi mărturie creştină azi ..., p. 109.

${ }^{15}$ Pr. Prof. Dr. Ion Bria, Curs de teologie şi practică misionară ortodoxă, pp. 75-76; Ion Bria, Postmodernism: An Emerging mission issue, în „International Review of Mission”, LXXXVI (1997), nr. 343, p. 420; Gheorghe Petraru, Pr. Prof. Dr. Ion Bria - universalizarea şi dinamizarea etosului misionar ortodox..., p. 216.

${ }^{16}$ Pr. Prof. Dr. Ion Bria, Curs de teologie şi practică misionară ortodoxă..., p. 95. ${ }^{17}$ Ion Bria, Postmodernism: An Emerging mission issue, p. 421. 


\section{Răzvan Emanuel FIBIŞAN}

Euharistie şi slujire, pentru că viaţa liturgică, euharistică a Bisericii este fără îndoială un eveniment de revărsare a iubirii lui Dumnezeu faţă de oameni sau, cu alte cuvinte, un eveniment misiologic ${ }^{18}$. Aşa se explică de ce, în gândirea părintelui Bria, diaconia liturgică sau ,liturghia fratelui" decurge din comuniunea euharistică, fiind, totodată, una din cerinţele ei radicale. Se poate spune că, pentru teologul nostru, viaţa liturgică a Bisericii nu este numai o paradigmă pentru stilul de viaţă creştină, ci şi o paradigmă pentru restabilirea relaţiei dintre oameni şi Dumnezeu, dintre oameni şi natură, dar şi a relaţiilor autentice dintre diferitele categorii de oameni ${ }^{19}$.

Prin toate aceasta, părintele reliefează: 1. că Liturghia euharistică nu trebuie să fie limitată doar la celebrarea Euharistiei în interiorul Bisericii sau să fie percepută ca un eveniment închis, ci ea trebuie să fie o întruchipare permanentă, continuă a prezenţei lui Hristos în rândul tuturor oamenilor şi în toate locurile ${ }^{20}$. Iată ce spune părintele Bria: ,, a ţine comunitatea numai în timpul şi spaţiul liturgic, fără a-i da posibilitatea de a atinge societatea, de a fecunda cultura acesteia şi de a împlini năzuinţele ei, înseamnă nu numai atrofierea entuziasmului liturgic, ci şi alterarea naturii sale proprii, aceea de a fi sarea pământului şi lumina lumii. Căci există o legătură particulară

${ }^{18}$ Ion Bria, A new typology for Gospel and Culture syntax: From an Eastern European Orthodox Perspective, în „International Review of Mission”, LXXXIV (1995), nr. 334, p. 281.

${ }^{19} \mathrm{Cf}$. Père Ion Bria, L'unité de l'Eglise et le renouveau de la communauté humaine, în „Istina”, XXVII (1982), nr. 1, p. 30; Pr. Prof. Dr. Ion Bria, Curs de teologie şi practică misionară ortodoxă ..., p. 108. Părintele Bria chiar spune că Euharistia sau comuniunea euharistică presupune identificarea cu acei oamenii defavorizaţi, săraci, flămânzi, neîndreptăţiţi. Ca atare, comunitatea parohială, prin împărtăşirea euharistică, pe lângă faptul că devine unită şi închegată, ea se poate implica în misiune faţă de acei oameni care se află în nevoi. - Ion Bria, Renewal of the Tradition through pastoral witness, în ,International Review of Mission", nr. 258, 1976, p. 185.

${ }^{20}$ Ion Bria, The Church's Role in Evanghelism: Icon or Platform?, în „International Review of Mission”, LXIV (1975), nr. 255, p. 248. 
între spiritualitatea liturgică şi etica socială creştină"”n ${ }^{21}$. Aşadar, prin Euharistie, Liturghia trece chiar dincolo de limitele cultului creştin, continuând în vieţile credincioşilor într-o varietate de "liturghii”"22; 2. că spiritualitatea liturgică a fiecărei parohii nu se limitează la locaşul de cult şi nici nu se încheie cu primirea Sfintei Euharistii, ci ea continuă sub diverse forme în toate aspectele vieţii sociale şi personale ${ }^{23}$; şi 3. că, din perspectiva synaxei euharistice, parohia desfăşoară trei activităţi sau mai bine zis o întreită activitate: pastorală sau de hrănire, misionară sau de mărturie şi diaconală sau de slujire ${ }^{24}$.

Din cele prezentate, se poate constata că, în gândirea părintelui Ion Bria, împărtăşirea de Hristos este calea ce duce la împlinirea unei exigenţe teologice şi ecleziale şi, totodată, calea pentru recuperarea identităţii ciuntite de diferite ideologii, de absolutizarea unor principii materialiste, consumeriste şi hedoniste. De asemenea, se poate constata că fără o reînviorare euharistică nu este posibilă o reînviorare a parohiei, ca adunare liturgică ce se desăvârşeşte la masa lui Hristos în împărăţia Lui, pentru că reînviorarea euharistică este singura care poate să dea viaţă şi să integreze unul într-altul darurile şi harismele tuturor mădularelor Trupului lui Hristos ${ }^{25}$.

${ }^{21}$ Pr. Prof. Dr. Ion Bria, Curs de teologie şi practică misionară ortodoxă, p. 83.

${ }^{22}$ Ion Bria, Mission and Secularization in Europe, în ,International Review of Mission", LXXVII (1988), nr. 305, pp. 125, 130; Ion Bria, Dynamics of Liturgy in Mission, în „International Review of Mission”, LXXXII (1993), nr. 327, pp. 317-318. Concedierea/Trimiterea credincioşilor la sfârşitul Liturghiei prin cuvintele „Cu pace să ieşim!” nu înseamnă că ea s-a sfârşit, ci că ea trebuie transpusă în alte forme, în care să continue - Ion Bria, Go Forth in Peace. A pastoral and missionary Guidebook, Commission on World Mission and Evangelism, Geneva, WCC, 1982, p. 32.

${ }^{23}$ Pr. Prof. Dr. Ion Bria, Destinul Ortodoxiei ..., p. 319.

${ }^{24}$ Pr. Prof. Dr. Ion Bria, Curs de teologie şi practică misionară ortodoxă..., pp. 49-50, 88; Idem, Curs de formare misionară şi ecumenică..., p. 22.

${ }^{25}$ Cf. Pr. Prof. Dr. Ion Bria, Liturghia după Liturghie. Misiunea apostolică şi mărturie creştină azi..., p. 113. 


\section{Bibliografie}

1. Bria, Ion, A new typology for Gospel and Culture syntax: From an Eastern European Orthodox Perspective, în „International Review of Mission", LXXXIV (1995), nr. 334, pp. 273-283.

2. Idem, Curs de teologie şi practică misionară ortodoxă, Genève, 1982.

3. Idem, Curs de formare misionară şi ecumenică, Geneva, 1984.

4. Idem, Destinul Ortodoxiei, Bucureşti, Editura Institutului Biblic şi de Misiune al Bisericii Ortodoxe Române, 1989.

5. Idem, Dynamics of Liturgy in Mission, în ,International Review of Mission”, LXXXII (1993), nr. 327, pp. 317-325.

6. Go Forth in Peace. A pastoral and missionary Guidebook, Commission on World Mission and Evangelism, Geneva, WCC, 1982.

7. Idem, Liturghia după Liturghie. Misiunea apostolică şi mărturie creştină azi, Editura Athena, 1996.

8. Idem, Liturgie et mission, în „Dictionnaire oecuménique de missiologie. Cent mots pour la mission", sous la direction de Ion Bria, Philippe Chanson, Jacques Gadille, Marc Spindler, ParisGeneve-Yaoundé: Edition du Cerf, Labo et Fides, CLE Yaoundé, 2001.

9. Idem, L'unité de l'Eglise et le renouveau de la communauté humaine, în „Istina”, XXVII (1982), nr. 1, pp 24-32.

10. Idem, Mission and Secularization in Europe, în „International Review of Mission", LXXVII (1988), nr. 305, pp. 117-130.

11. Idem, Ortodoxia în Europa. Locul spiritualităţii române, Iaşi, Editura Mitropoliei Moldovei şi Bucovinei, 1995.

12. Idem, Postmodernism: An Emerging mission issue, în „International Review of Mission”, LXXXVI (1997), nr. 343, pp. 417-423.

13. Idem, Reflection on Mission Theology and Methodology, în „International Review of Mission”, nr. 289, 1984, pp. 66-72.

14. Idem, Renewal of the Tradition through pastoral witness, în „International Review of Mission”, nr. 258, 1976, pp. 182-185.

15. Idem, Spre plinirea Evangheliei. Dincolo de apărarea Ortodoxiei: exegeza şi transmiterea Tradiţiei, Alba-Iulia, Editura 
Reîntregirea, 2002.

16. Idem, The Church's Role in Evanghelism: Icon or Platform?, în „International Review of Mission”, LXIV (1975), nr. 255, pp. 243-250.

17. Idem, The Liturgy after the Liturgy. Mission and Witness from an Orthodox Perspective, Geneva, WCC Publications, 1996.

18. Idem, Unity and Mission. From the Perspective of the local Church: an Orthodox View, în „The Ecumenical Review”, XXXIX (1987), nr. 3, pp. 265-270.

19. Petraru, Gheorghe, Pr. Prof. Dr. Ion Bria - universalizarea şi dinamizarea etosului misionar ortodox, în Rev. ph. D. Ioan Tulcan şi ph. D. Cristinel Ioja (coord.), „Omagiu Părintelui Prof. Dr. Ion Bria (1929-2002): The reception of his theological thinking an its relevance for the overpass of the ecumenical \&missionary deadlock”, Arad, Editura Universităţii „Aurel Vlaicu", 2009, pp. 204-219. 